\title{
Improvements in the Quality of Agricultural Soils Following Organic Material Additions Depend on Both the Quantity and Quality of the Materials Applied
}

\author{
Anne Bhogal ${ }^{1 *}$, Fiona A. Nicholson ${ }^{1}$, Alison Rollett ${ }^{1}$, Matt Taylor ${ }^{2}$, Audrey Litterick ${ }^{3}$, \\ Mark J. Whittingham ${ }^{4}$ and John R. Williams ${ }^{5}$ \\ ${ }^{1}$ ADAS Gleadthorpe, Mansfield, United Kingdom, ${ }^{2}$ Grieve Strategic Ltd., Shipston on Stour, United Kingdom, ${ }^{3}$ Earthcare \\ Technical Ltd., Waterlooville, United Kingdom, ${ }^{4}$ School of Biology, Newcastle University, Newcastle upon Tyne, \\ United Kingdom, ${ }^{5}$ ADAS Boxworth, Cambridge, United Kingdom
}

OPEN ACCESS

Edited by:

Francisco Javier Salazar Remehue Regional Research Center, Institute of Agricultural Research, Chile

Reviewed by:

Peter Sørensen

Aarhus University, Denmark

João Coutinho,

University of Trás-os-Montes and Alto

Douro, Portugal

*Correspondence:

Anne Bhogal

anne.bhogal@adas.co.uk

Specialty section This article was submitted to

Waste Management in

Agroecosystems,

a section of the journal

Frontiers in Sustainable Food Systems

Received: 05 December 2017 Accepted: 26 March 2018 Published: 19 April 2018

Citation:

Bhogal A, Nicholson FA, Rollett $A$, Taylor M, Litterick A, Whittingham MJ and Williams JR (2018) Improvements

in the Quality of Agricultural Soils

Following Organic Material Additions

Depend on Both the Quantity and Quality of the Materials Applied. Front. Sustain. Food Syst. 2:9. doi: 10.3389/fsufs.2018.00009
It is widely recognized that the application of organic materials is one of the most effective ways of increasing soil organic carbon (SOC) levels and improving soil quality, but do all forms of organic matter input have the same impact on soil properties A network of seven experimental sites investigated the effects on soil quality of annual applications over a minimum of 3 years of compost and food-based digestate in comparison with farmyard manure (FYM) and livestock slurry. Two of the sites were existing experimental platforms which had previously benefitted from applications of FYM, livestock slurry and green compost allowing the effects of longer-term applications (6-17 years) on soil properties to be quantified. The application of all organic materials increased soil nutrient supply (total nitrogen, extractable phosphorus, potassium, and magnesium) within a short timescale ( $<3$ years), whereas SOC contents were only increased following the long-term (9 years or more) application of bulky organic materials (compost and FYM). SOC increases were associated with improvements in soil biological (microbial biomass) and physical properties (reduced bulk density), although the level of improvement was dependent on the quality of the organic material applied (as determined by its lignin content, an indicator of resistance to decomposition). Applications of low dry matter content materials (digestates and livestock slurries) had a limited capacity to improve soil biological and physical functioning, due to their low organic matter loading.

Keywords: organic materials, soil organic carbon, soil quality, digestate, compost

\section{INTRODUCTION}

The application of organic materials to agricultural soils is a widely recommended practice not only as a source of essential plant nutrients which can provide savings in inorganic fertilizer use (Defra, 2010), but also as a means of increasing soil organic carbon (SOC) levels with associated improvements in soil biological and physical functioning (Bhogal et al., 2009). Indeed, the benefit of a range of organic material applications (livestock manures, composts, biosolids, etc.,) for SOC 
and soil quality has been widely documented and reviewed (e.g., Edmeades, 2003; Johnston et al., 2009). Studies have been conducted to evaluate the potential of organic materials as nutrient sources (Schröder et al., 2005) and soil conditioners (Diacono and Montemurro, 2010), as well as a means to sequester carbon (C) in the mitigation of climate change (Powlson et al., 2012).

Developing nutrient management and circular economy policies (e.g., European Union, 2015) have led to increasing amounts of organic materials being directed away from landfill and beneficially recycled to agricultural land, to complete natural nutrient and $\mathrm{C}$ cycles. Consequently, the utilization of a wide range of "alternative" organic materials to the more traditional livestock manures is being actively encouraged within agricultural systems. Notably the anaerobic digestion of sourcesegregated food waste is an area of significant growth in the UK, with around $5 \mathrm{Mt}$ of the $7 \mathrm{Mt}$ of food waste currently sent to landfill each year predicted to be available for digestion by 2020 (DECC and Defra, 2011). In order to provide confidence in the use of these materials within agricultural systems, it is important to demonstrate their long-term effects on soil and food quality as well as developing sustainable nutrient management practices by minimizing environmental losses (Bhogal et al., 2016; Nicholson et al., 2017).

The long-term impact of digestates on soil properties is a largely unexplored area of research, particularly where food waste is the feedstock (Nkoa, 2014), but can lessons be learnt from the application of other, similar organic materials such as livestock slurries? Do all organic carbon (OC) inputs have the same impact on soil properties regardless of the source? For example, changes in the total SOC pool have been shown to depend on the amount of organic material (C) applied, but not on the type of material (e.g., Rasmussen et al., 1980) whereas there is conflicting evidence on the response of other soil properties to the type of material applied. For example, Bhogal et al. (2009) observed that repeated OC inputs (for at least 7 years) in the form of livestock manures led to improvements in soil physical properties (bulk density, porosity, and available water capacity) whereas OC additions in the form of crop residues (straw) did not. By contrast, Peltre et al. (2015) measured changes in specific draft force that were related to the amount of OC applied and its effect on bulk density rather than due to differences in the type of organic material (including compost, livestock manures and sewage sludge applied annually over 11 years).

A recent research programme evaluating the use of digestate and compost derived from food waste in UK agriculture has provided a good opportunity to explore some of these issues ("DC-Agri," www.wrap.org.uk/dc-agri). At its inception (in 2010) there were less than five commercially operated anaerobic digestion (AD) plants processing food waste in the UK, compared to over 100 plants currently in operation (2016), returning c.1.4 Mt digestate to agricultural soils on an annual basis (WRAP, 2014). This compares to the annual return of c.93 Mt of farm manures (Nicholson et al., 2008), 1.1 Mt of biosolids (Water, 2010) and 1.3 Mt of compost (c. $20 \%$ as green/food compost; WRAP, 2013). The experimental programme evaluated the soil quality implications of repeated applications of food-based digestate and green/food compost and included comparator materials more commonly applied to agricultural soils (livestock manures, green compost). This paper uses the results from this work to determine whether the soil quality benefits of organic materials depend on the amount (number of applications $\times$ OC content) or on the form of OC applied.

\section{MATERIALS AND METHODS \\ Experimental Sites and Treatments}

In autumn 2010, a network of seven sites was established on a range of soil types and across different agroclimatic zones in Great Britain, namely: Aberdeen and Ayr in Scotland, Devizes, Faringdon, Harper Adams, and Terrington in England, and Lampeter in Wales (Table 1). Two of the sites were permanent (cut) grassland and five were in an arable rotation. At each site, 18 experimental plots $\left(60-160 \mathrm{~m}^{2}\right.$ in size, depending on the

TABLE 1 | Experimental site details.

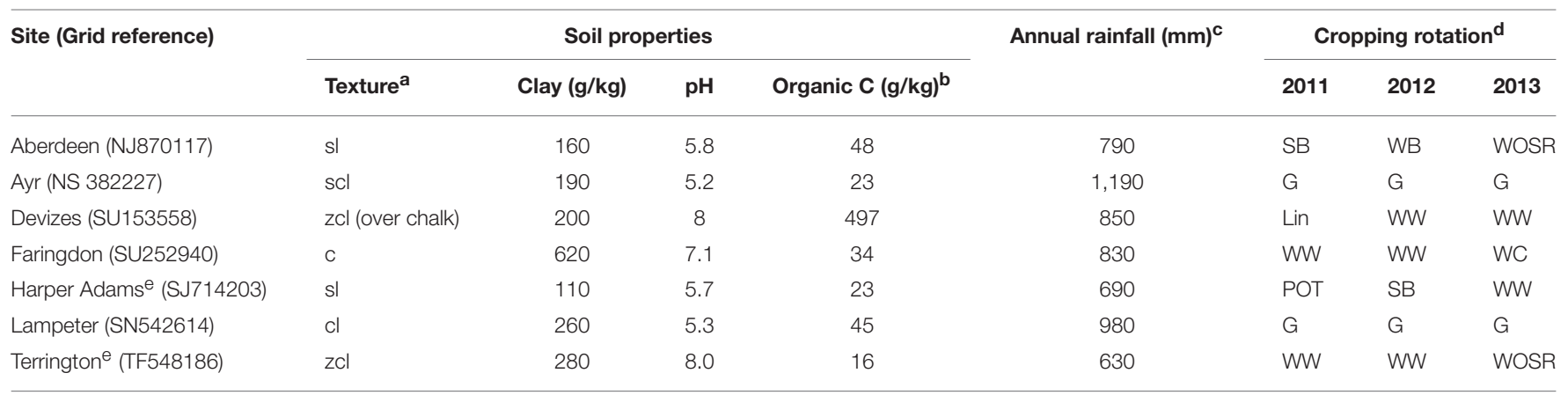

${ }^{a}$ sl, sandy loam; scl, sandy clay loam; zcl, silty clay loam; c, clay; cl, clay loam.

${ }^{b}$ Measured on the control treatment at the beginning of the experiment.

c30 year average annual rainfall.

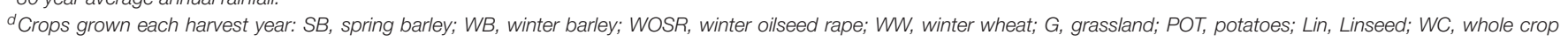
oats/peas.

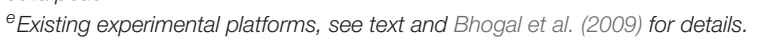


site) were laid out in a randomized block design comprising three replicates of six treatments (five organic materials and a control receiving inorganic fertilizer only; Table 2). Crops were grown according to best farm practice using commercially recommended seed rates, with crop protection products applied according to good agricultural practice to control weeds, pests and diseases, with the aim of growing healthy and productive crops. At the arable sites, annual cultivations (by plow/disc $\leq 25 \mathrm{~cm}$ deep) occurred in opposite directions each year to minimize soil movement between the plots. The grass sites were cut twice during each season for silage.

In the first cropping year, organic materials were applied in autumn 2010 at Ayr and Terrington, and at the other sites (Aberdeen, Devizes, Faringdon, Harper Adams, and Lampeter) once ground conditions and Nitrate Vulnerable Zone (NVZ) regulations allowed in spring 2011. Organic material applications were repeated in autumn 2011 at Aberdeen, Devizes, Faringdon, Lampeter, and Terrington and in spring 2012 at Ayr and Harper Adams, with a final application in autumn 2012 at all seven sites. Cattle farmyard manure (FYM) and slurries were used at all sites (from sources local to each site), except Terrington where pig manures (FYM and slurry) were used. The sites at Harper Adams and Terrington were existing experimental platforms and had previously benefitted from applications of FYM and livestock slurry for 16-17 years prior to 2010 and green compost for 6 years (Bhogal et al., 2009, 2011), with Harper Adams also previously receiving food-based digestate applications for 3 years. At Aberdeen, green compost had also been previously applied for 1 year (Litterick, 2009). All the digestate and composts used at the experimental sites were certified quality products according to the PAS Assurance Schemes (PAS 100 for composts and PAS 110 for digestates; BSI, 2011, 2014).

All the high-dry matter (solid) organic materials were applied at a target rate of $c .250 \mathrm{~kg}$ nitrogen $(\mathrm{N}) / \mathrm{ha}$, and the low dry matter (liquid) materials were applied at rates between 120 and $250 \mathrm{~kg} \mathrm{~N} / \mathrm{ha}$, depending on the volume (restricted to $\leq 80 \mathrm{~m}^{3} / \mathrm{ha}$ ) and based on analysis provided by the supplier. Supplementary inorganic fertilizer $\mathrm{N}$ was applied to all treatments to balance crop $\mathrm{N}$ supply with that recommended for the crop, in line with the control treatment, using MANNER-NPK predictions of organic material crop available $\mathrm{N}$ supply (Nicholson et al., 2013). Phosphate $\left(\mathrm{P}_{2} \mathrm{O}_{5}\right)$, potash $\left(\mathrm{K}_{2} \mathrm{O}\right)$ and sulfur $\left(\mathrm{SO}_{3}\right)$ were applied at a single rate to all treatments, based on the requirements of the untreated control (Defra, 2010; SAC, 2010). Mineral fertilizer

TABLE 2 | Experimental treatments.

\begin{tabular}{ll}
\hline Treatment & \multicolumn{1}{c}{ Details } \\
\hline 1 & $\begin{array}{l}\text { Control (no organic material application; recommended rates } \\
\text { of inorganic fertilizer) }\end{array}$ \\
2 & Green compost equivalent to $250 \mathrm{~kg} \mathrm{~N} / \mathrm{ha}$ \\
3 & Green/food compost equivalent to $250 \mathrm{~kg} \mathrm{~N} / \mathrm{ha}$ \\
4 & Food-based digestate equivalent to $120-250 \mathrm{~kg} \mathrm{~N} / \mathrm{ha}$ \\
5 & Farmyard manure equivalent to $250 \mathrm{~kg} \mathrm{~N} / \mathrm{ha}$ \\
6 & Livestock slurry equivalent to $120-250 \mathrm{~kg} \mathrm{~N} / \mathrm{ha}$
\end{tabular}

applications aimed to ensure (as far as was practically possible) that no major nutrient limited crop growth, and that crop yields and residue returns were the same on all treatments (i.e., the only difference in OC inputs was from the applied organic material treatments).

Triplicate samples of each organic material were taken at spreading every year and analyzed as detailed in Table 3 . In some years there were slight discrepancies between the total $\mathrm{N}$ analysis provided by the organic material supplier (which was used to calculate application rates) and that determined at the time of application, which, on some occasions, led to $\mathrm{N}$ loadings in excess of the target rate (Table 3). Over all the sites, the average annual $\mathrm{N}$ loading was close to the target ranges at c.160-250 $\mathrm{kg} / \mathrm{ha} / \mathrm{yr}$ total N (Table 3). FYM supplied the most P, K and S, compost the most total $\mathrm{N}$ (although over $95 \%$ of this was in slowly available organic forms), and the food-based digestate and livestock slurry supplied the most readily available N (RAN; Table 3).

\section{Soil Quality Measurements}

In spring 2013, c.6 months following the final application of treatments, a range of topsoil $(0-15 \mathrm{~cm})$ chemical, biological, and physical properties were measured at each site (Table 4). This involved taking $c .5 \mathrm{~kg}$ topsoil from each plot for determination of soil chemical properties, microbial biomass, respiration and potentially mineralisable $\mathrm{N}(\mathrm{PMN})$, three replicate intact soil cores $(0-5 \mathrm{~cm}$ depth) per plot for determination of soil bulk density, porosity and water held at field capacity, and a representative $500 \mathrm{~g} /$ plot topsoil sample for determination of water held at 2 and 15 bar. Shear strength (10 vanes/plot) and penetration resistance (10 penetrometer readings/plot) were determined in the field.

\section{Data Analysis}

At each site, the effect of the different organic material treatments on soil quality was evaluated using conventional analysis of variance (ANOVA) and comparison of $P$-values; post-hoc testing was undertaken to evaluate which treatment means were different from each other using a Duncan's multiple range test (using Genstat version 12; VSN International Ltd., 2010).

Multi-predictor models (using R statistical software; R Core Team, 2014) were then used to establish whether differences observed at the individual sites were consistent across all sites or whether the responses differed with site (i.e., soil type and climatic conditions), land use (grass/arable) and prior history (i.e., whether the sites had a previous history of repeated organic material additions, as at Harper Adams and Terrington; Aberdeen was not included as a site with a prior history as green compost had only been applied for 1 year). Both generalized linear mixed models (GLMMs) and general linear models (GLMs) were used, with experimental site included as a random effect in the former and as a fixed effect in the latter, with all models nested. The importance of individual predictors within the models (i.e., site, land-use and prior history) was assessed by comparing Akaike's Information Criteria (AIC) values (i.e., a lower AIC value indicated a better fit), with an improvement in AIC of greater than six indicating a substantially improved 
TABLE 3 | Organic material analyses and annual loading rates, 2010-2013 (mean with standard error in parenthesis; $n=21^{a}$ ).

\begin{tabular}{|c|c|c|c|c|c|c|}
\hline Determinant & Units $^{b}$ & Food-based digestate & Livestock slurry & Green compost & Green/food compost & Farmyard manure \\
\hline $\mathrm{pH}$ & - & $8.50(0.06)$ & $7.37(0.09)$ & $8.26(0.09)$ & $7.91(0.10)$ & $8.16(0.13)$ \\
\hline Dry matter & $\mathrm{g} / \mathrm{kg}$ & $21.6(1.8)$ & $46(4.7)$ & $700(30.0)$ & $660(16.6)$ & $270(22.5)$ \\
\hline Total nitrogen (N) & $\mathrm{kg} / \mathrm{t} \mathrm{fw}$ & $4.67(0.18)$ & $2.67(0.14)$ & $9.59(0.49)$ & $11.8(0.63)$ & $6.67(0.53)$ \\
\hline $\mathrm{RAN}^{\mathrm{C}}$ & $\mathrm{kg} / \mathrm{t} \mathrm{fw}$ & $3.78(0.17)$ & $1.44(0.12)$ & $0.24(0.03)$ & $0.81(0.10)$ & $0.46(0.09)$ \\
\hline$\%$ of total nitrogen & & $81(1.54)$ & $54(3.2)$ & $2(0.34)$ & $7(0.54)$ & $7(1.36)$ \\
\hline Total phosphate $\left(\mathrm{P}_{2} \mathrm{O}_{5}\right)$ & $\mathrm{kg} / \mathrm{t} \mathrm{fw}$ & $0.61(0.07)$ & $0.69(0.05)$ & $3.59(0.21)$ & $4.16(0.30)$ & $4.27(0.54)$ \\
\hline Total potash $\left(\mathrm{K}_{2} \mathrm{O}\right)$ & $\mathrm{kg} / \mathrm{t} \mathrm{fw}$ & $1.96(0.08)$ & $2.29(0.17)$ & $6.93(0.48)$ & $6.48(0.28)$ & $7.98(0.90)$ \\
\hline Total magnesium (MgO) & $\mathrm{kg} / \mathrm{t} \mathrm{fw}$ & $0.07(0.01)$ & $0.49(0.05)$ & $3.68(0.16)$ & $3.66(0.15)$ & $2.65(0.22)$ \\
\hline Total sulfur $\left(\mathrm{SO}_{3}\right)$ & $\mathrm{kg} / \mathrm{t} \mathrm{fw}$ & $0.36(0.06)$ & $0.78(0.16)$ & $3.30(0.19)$ & $3.74(0.14)$ & $5.23(0.93)$ \\
\hline Organic carbon & $\mathrm{g} / \mathrm{kg} \mathrm{dm}$ & $331(8.8)$ & $380(10.2)$ & $172(7.2)$ & $184(6.3)$ & $305(17.5)$ \\
\hline Lignin carbon & $\mathrm{g} / \mathrm{kg} \mathrm{dm}$ & $67(10.2)$ & $68(7.5)$ & $115(5.9)$ & $109(4.0)$ & $170(15.1)$ \\
\hline$\%$ of total carbon & & $21(2.91)$ & $18(1.89)$ & $68(2.98)$ & $62(2.95)$ & $55(3.79)$ \\
\hline \multicolumn{7}{|c|}{ ANNUAL LOADING RATE } \\
\hline Total nitrogen $(N)$ & $\mathrm{kg} / \mathrm{ha} / \mathrm{yr}$ & $220(13.5)$ & $192(12.6)$ & $261(12.3)$ & $211(9.5)$ & $247(18.1)$ \\
\hline RAN & $\mathrm{kg} / \mathrm{ha} / \mathrm{yr}$ & $178(12.6)$ & $102(8.1)$ & $6(0.9)$ & $14(1.4)$ & $17(3.2)$ \\
\hline Total phosphate $\left(\mathrm{P}_{2} \mathrm{O}_{5}\right)$ & $\mathrm{kg} / \mathrm{ha} / \mathrm{yr}$ & $29(3.6)$ & $51(4.6)$ & $97(4.0)$ & $74(4.5)$ & $159(19.5)$ \\
\hline Total potash $\left(\mathrm{K}_{2} \mathrm{O}\right)$ & $\mathrm{kg} / \mathrm{ha} / \mathrm{yr}$ & $92(6.0)$ & $167(15.3)$ & $186(9.0)$ & $117(6.6)$ & $294(30.9)$ \\
\hline Total magnesium (MgO) & $\mathrm{kg} / \mathrm{ha} / \mathrm{yr}$ & $3(0.58)$ & $36(4.4)$ & $104(6.7)$ & $67(4.0)$ & $99(7.8)$ \\
\hline Total sulfur $\left(\mathrm{SO}_{3}\right)$ & $\mathrm{kg} / \mathrm{ha} / \mathrm{yr}$ & $16(1.9)$ & $58(13.5)$ & 89 (3.3) & $67(3.2)$ & $193(34)$ \\
\hline
\end{tabular}

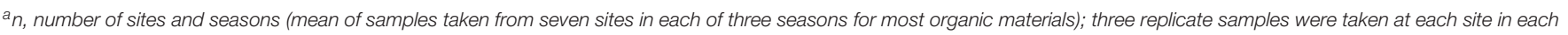
season.

${ }^{b} \mathrm{~kg} / \mathrm{t}$ fw, kilograms/ton fresh weight; \% dm, percent dry matter.

${ }^{c} R A N$, Readily available nitrogen (i.e., ammonium- $N+$ nitrate- $N$ ).

fit (i.e., a meaningful difference) and values of between two and six a minor improvement (Richards, 2005, 2008). This approach is well-recognized (e.g., Verzani, 2014), with the results from the models supported by observed patterns in the data. Most of the multi-predictor models assumed a normal distribution, with responses transformed to normality as required (e.g., by $\log$ transforming data). Model fits were assessed using standard diagnostics such as Quantile-Quantile (QQ) plots. Due to poorly distributed data, SOC was analyzed using the non-parametric Kruskal-Wallis Test, a one-way test of response variable vs. treatment, without controlling for site.

\section{RESULTS}

\section{Organic Carbon Loading Rates}

Total OC loadings from the organic materials applied over the 3 year experimental period, together with OC loadings from historic applications (at Harper Adams and Terrington), are summarized in Table 5. Over the 3 year experimental programme the green compost and FYM treatments supplied similar amounts of OC (c.9 t/ha OC), the green/food compost $c .7$ t/ha OC, livestock slurry $c .5 \mathrm{t} / \mathrm{ha}$ OC and food-based digestate $c .1$ $\mathrm{t} / \mathrm{ha} \mathrm{OC}$, with differences between the sites reflecting the different sources and hence composition of the organic materials. Harper Adams and Terrington were existing experimental platforms and had benefitted from historic applications of FYM, slurry, and green compost, and at Harper Adams from food-based digestate applications. The recent and historic organic material applications extended the range of OC loadings from $<1 \mathrm{t} /$ ha OC up to $c .50 \mathrm{t} / \mathrm{ha}$ OC.

\section{Effect of Organic Material Additions on Soil Quality}

There was a substantial improvement in model fit when site was included in the multi-predictor model (AIC values improved by $>6$ in many cases) for nearly all of the measured parameters (Table 6), which was not surprising given the range of soil types and agroclimatic locations. However, land-use (grass vs. arable) and prior history (i.e., whether there was previous history of organic material additions) also had an impact on the response of some parameters to the treatments applied (Table 6). As the underlying baseline soil conditions varied across the sites, the results have been presented as a percentage difference from the control treatments in order to normalize the data and identify the overall direction of change in soil properties as a result of the organic material additions across all the sites. Error bars have therefore not been shown on the charts, as these would be misleading given they would be due to variations in both site and treatment. For the full (individual site) experimental results ${ }^{1}$

\section{Soil Organic Carbon}

Topsoil SOC contents were highly variable across the sites, despite this, the Kruskal-Wallis test indicated a significant

\footnotetext{
${ }^{1}$ http://www.wrap.org.uk/content/digestate-and-compost-agriculture-dc-agrireports.
} 
treatment effect $(P<0.001$; Table 6). Inspection of the individual site ANOVAs revealed that treatment effects were only evident at the two sites with a prior history of green compost, FYM and livestock slurry applications (i.e., Harper Adams and Terrington). Here, there was clear evidence that repeated applications of bulky organic materials for 9 years or more increased SOC (Figure 1), with both green compost and FYM resulting in a

TABLE 4 | Soil quality measurements and methodologies.

\begin{tabular}{|c|c|}
\hline Soil property & Method \\
\hline \multicolumn{2}{|l|}{ CHEMICAL } \\
\hline Organic carbon (OC) & $\begin{array}{l}\text { Modified Walkley Black or “Tinsley” (MAFF, } \\
\text { 1986) }\end{array}$ \\
\hline Total nitrogen $(\mathrm{N})$ & Kjeldahl (MAFF, 1986) \\
\hline $\mathrm{pH}$ & Water (MAFF, 1986) \\
\hline Extractable phosphorus $(\mathrm{P})$ & $\begin{array}{l}\text { Olsen (MAFF, 1986); Modified Morgan's (SAC, } \\
\text { 2010) }\end{array}$ \\
\hline $\begin{array}{l}\text { Extractable potassium }(\mathrm{K}) \text { and } \\
\text { magnesium }(\mathrm{Mg})\end{array}$ & Ammonium nitrate (MAFF, 1986) \\
\hline Cation exchange capacity (CEC) & Ammonium acetate (MAFF, 1986) \\
\hline \multicolumn{2}{|l|}{ BIOLOGICAL } \\
\hline Biomass $\mathrm{C}$ and $\mathrm{N}$ & $\begin{array}{l}\text { Chloroform-extraction (Brookes et al., 1985). } \\
\text { Correction factor = } 2.22 \text { (Wu et al., 1990) }\end{array}$ \\
\hline Respiration & $\begin{array}{l}\text { Alkali }(\mathrm{KOH}) \text { absorption under controlled } \\
\text { laboratory conditions (Anderson and Domsch, } \\
\text { 1989) }\end{array}$ \\
\hline $\begin{array}{l}\text { Potentially mineralisable nitrogen } \\
(\mathrm{PMN})\end{array}$ & Anaerobic incubation (Keeney, 1982) \\
\hline \multicolumn{2}{|l|}{ PHYSICAL } \\
\hline $\begin{array}{l}\text { Total available water capacity } \\
\text { (AWC) and Easily available water } \\
\text { capacity (EAWC) }\end{array}$ & $\begin{array}{l}\text { Volumetric moisture content between } 0.05 \text { and } \\
15 \text { bar or } 0.05 \text { and } 2 \text { bar, respectively (MAFF, } \\
\text { 1982) }\end{array}$ \\
\hline Bulk density & Intact soil cores (MAFF, 1982) \\
\hline Porosity & $\begin{array}{l}\text { Porosity }=1-\text { (bulk density/particle } \\
\text { density)*100; where particle density }=2.65 \\
(\text { MAFF, 1982) }\end{array}$ \\
\hline Shear strength & $\begin{array}{l}\text { Field: "pilcon" shear vane to } 7.5 \text { cm (MAFF, } \\
\text { 1982) }\end{array}$ \\
\hline Penetration resistance & Field: penetrometer to $15 \mathrm{~cm}$ (MAFF, 1982) \\
\hline
\end{tabular}

c. $20-25 \%$ increase in SOC relative to the fertilizer only control treatment, equivalent to an additional 5-6 t/ha SOC in the topsoil (calculated using the measured bulk density). Where these materials had been applied for only 3 years (as at the other five experimental sites) and similarly for the green/food compost additions (which were applied for 3 years at all sites) there were small but non-significant increases in SOC (Figure 1). The application of organic materials with a low dry matter content (i.e., livestock slurry and digestate) had very little impact on SOC levels (Figure 1) such that even after almost 20 years of repeated livestock slurry additions at Harper Adams and Terrington (supplying up to $26 \mathrm{t} / \mathrm{ha}$ OC; Table 5), the 5-10\% increase in SOC was not statistically significant $(P>0.05)$.

Although the 9 years of green compost applications supplied only half the OC $(c .30 \mathrm{t} / \mathrm{ha})$ that had been supplied by the almost 20 years of FYM applications (50-60 t/ha OC), it resulted in a comparable increase in total SOC levels. Retention of the OC (i.e., the increase in SOC relative to the control treatment expressed as a percentage of the total $\mathrm{C}$ loading) following the green compost additions (20-24\%) was therefore almost double that from FYM (12\%), which suggested the green compost was more resistant to decomposition. This was supported by the lignin composition of the applied materials, with the green compost containing $c .70 \%$ lignin compared to $c .55 \%$ in the FYM (Table 3).

\section{Soil Microbial Biomass}

The multipredictor modeling suggested that there was no treatment effect on microbial biomass $\mathrm{C}$, but a strong treatment $\times$ site interaction and prior history effect on biomass $\mathrm{N}$ (Table 6). The determination of microbial biomass involves analysis of the dissolved organic $\mathrm{C}$ and $\mathrm{N}$ content of a soil sample before and after fumigation, with the before-and-after difference equating to the microbial biomass (Brookes et al., 1985). Either the C or $\mathrm{N}$ content can be used as a measure of the size of the soil microbial population, with $\mathrm{C}$ contents typically larger, but more variable than $\mathrm{N}$ (with a microbial C: $\mathrm{N}$ ratio ranging between 4 and 8). This variability most likely explains the absence of any overall treatment or prior history effect on microbial biomass $\mathrm{C}$,

TABLE 5 | Total organic carbon loadings (t/ha) at the experimental sites.

\begin{tabular}{|c|c|c|c|c|c|c|c|}
\hline Treatment & Aberdeen & Ayr & Devizes & Faringdon & Harper Adams & Lampeter & Terrington \\
\hline Green compost & $14.5(13+1.5)^{\mathrm{a}}$ & 9.6 & 9.9 & 9.5 & $28.2(9.6+18.6)^{b}$ & 9.2 & $27.1(9.6+17.5)^{C}$ \\
\hline Green/food compost & $8.9(5.7+3.2)^{\mathrm{a}}$ & 6.7 & 6.2 & 5.6 & 5.1 & 6.8 & 7.5 \\
\hline Food-based digestate & 0.8 & 1.3 & 1.2 & 1.1 & $3.1(0.7+2.4)^{b}$ & 1.0 & 1.3 \\
\hline FYM & 8.0 & 8.2 & 9.0 & 7.9 & $61.1(10.6+50.5)^{b}$ & 10.4 & $46.9(11.1+35.8)^{\mathrm{C}}$ \\
\hline Slurry & 4.3 & 3.8 & 6.2 & 4.2 & $26.0(4.9+21.1)^{b}$ & 6.8 & $10.6(1.2+9.4)^{\mathrm{C}}$ \\
\hline
\end{tabular}

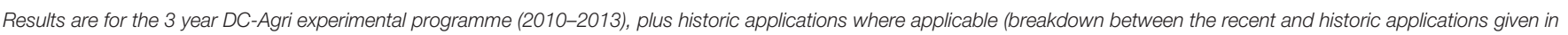
parenthesis).

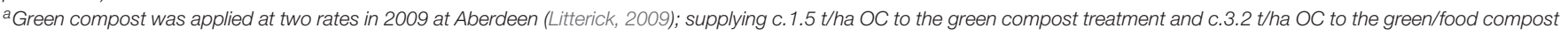
treatment.

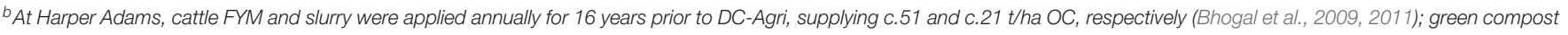
was introduced in 2004 and applied for 6 years, supplying c. 19 t/ha OC; food-based digestate was applied for 3 years, supplying c.2.4 t/ha OC (Charles Murray, pers. comm).

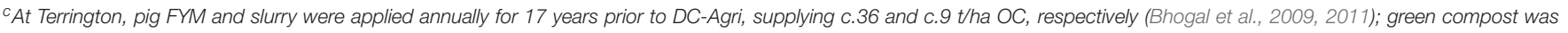
introduced in 2004 and applied for 6 years, supplying c. 18t/ha OC. 
TABLE 6 | Summary of multipredictor modeling results performed on data from all sites ${ }^{\mathrm{a}}$.

\begin{tabular}{|c|c|c|c|c|c|}
\hline Parameter ${ }^{b}$ & Site & Treatment & Treatment $\times$ Site & Grass/arable & Prior history \\
\hline Total N & $\mathrm{N}$ & $\star \star \star ~$ & * & $\mathrm{N}$ & $\mathrm{N}$ \\
\hline Extractable K & 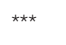 & 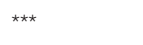 & $* \star \star$ & $\mathrm{N}$ & $\mathrm{N}$ \\
\hline Extractable Mg & $\mathrm{N}$ & $\mathrm{N}$ & $* * \star$ & $* \star \star$ & N \\
\hline Microbial biomass C (In) & 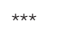 & $\mathrm{N}$ & $N$ & $\mathrm{~N}$ & $\mathrm{~N}$ \\
\hline Microbial biomass $\mathrm{N}(\mathrm{In})$ & 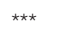 & * & 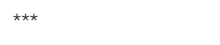 & $\mathrm{N}$ & $* \star \star$ \\
\hline Soil respiration (In) & 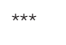 & $\mathrm{N}$ & $\mathrm{N}$ & $\mathrm{N}$ & $\mathrm{N}$ \\
\hline PMN (In) & 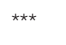 & 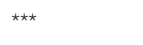 & $\mathrm{N}$ & $\mathrm{N}$ & $\mathrm{N}$ \\
\hline Bulk density & $\mathrm{N}$ & 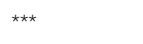 & $\mathrm{N}$ & 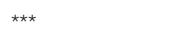 & * \\
\hline Moisture@2 bar & 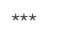 & * & 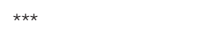 & $\star \star \star ~$ & $\mathrm{~N}$ \\
\hline Moisture@15bar & 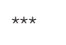 & * & 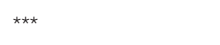 & 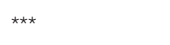 & $N$ \\
\hline Easily AWC & 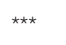 & * & $\mathrm{N}$ & 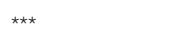 & $\mathrm{N}$ \\
\hline
\end{tabular}

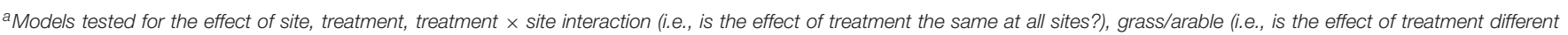

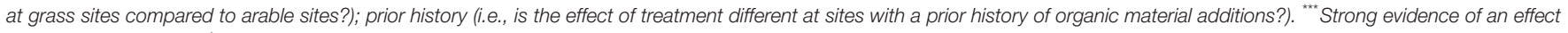

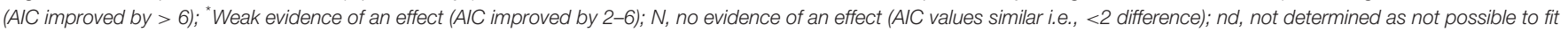

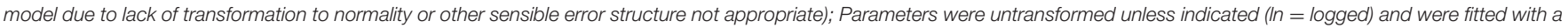
Gaussian Error Structure. Note that the main effects of "Site" or "Treatment" were assessed without the higher order interaction term included in the model.

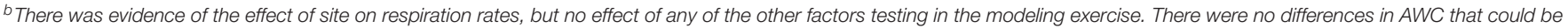
explained by the models. This confirmed the single site analyses, so AWC has not been included in this table.

${ }^{c * * *} P<0.001$ in the Kruskal-Wallis Test.

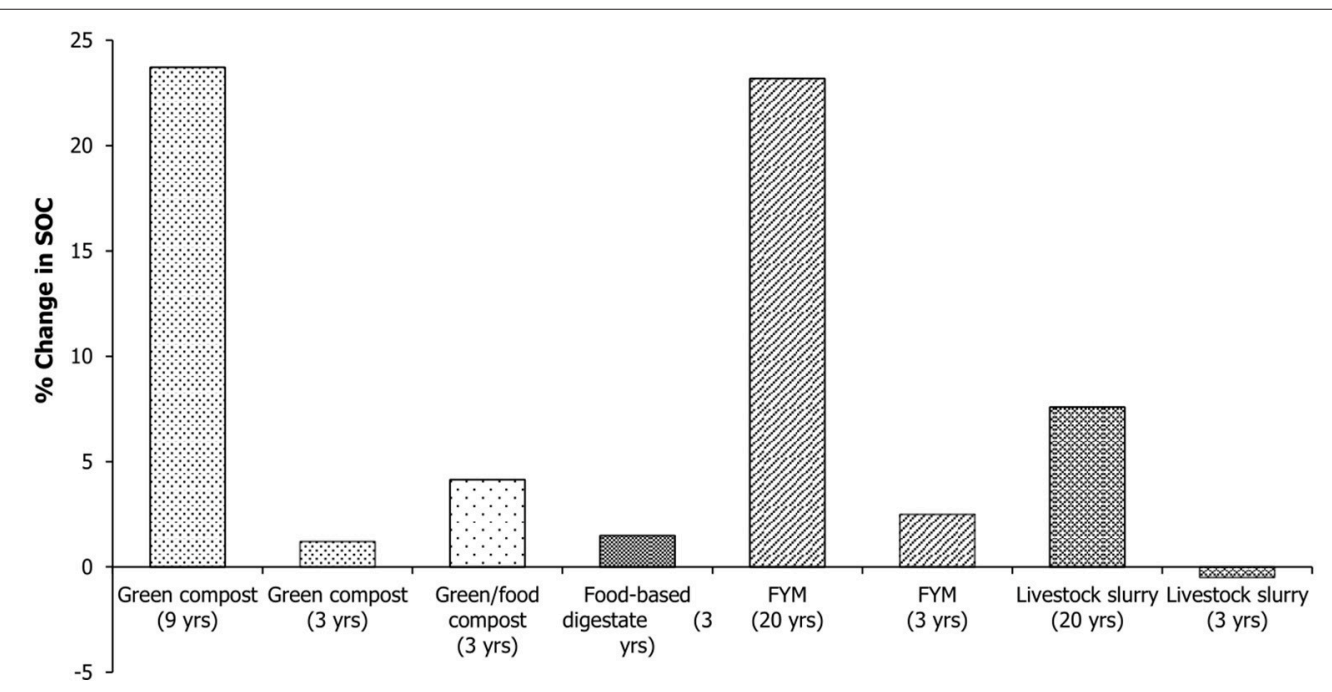

FIGURE 1 | Change in soil organic carbon (SOC) following the repeated addition of organic materials for 3 and 9-20 years. Results are expressed as a percentage difference from the control treatment averaged over two sites with a prior history of green compost, FYM, and slurry additions, five sites with 3 years of green compost, FYM, and slurry additions and seven sites with 3 years of food-based digestate and green/food compost additions.

despite this being evident in the microbial biomass $\mathrm{N}$ results. It is also surprising that there was no effect of land use (grass/arable) on both microbial biomass $\mathrm{C}$ and $\mathrm{N}$, although there were only two grassland sites compared to five arable sites in the dataset. Individual site ANOVAs confirmed the effect of prior history, with increases in both biomass $\mathrm{C}$ and $\mathrm{N}(P<0.01)$ only 
observed at the two sites (Harper Adams and Terrington) with a prior history of green compost, FYM and livestock slurry additions (Figures 2, 3). Although the repeated compost and FYM additions had the same effect on the total SOC pool (a $25 \%$ increase), the FYM had a proportionally greater effect on the soil microbial biomass increasing it by $50-60 \%$ compared to a c. $20 \%$ increase in biomass following repeated green compost additions (Figures 2, 3). Despite these differences in soil microbial biomass, topsoil respiration rates did not differ significantly $(P>0.05)$ between the treatments (Table 6).

\section{Soil Nutrient Supply}

As expected, the application of all the organic materials increased soil nutrient supply (Table 7) with improvements in topsoil total $\mathrm{N}$, extractable $\mathrm{P}$, extractable $\mathrm{Mg}(P<0.05$ at four of the seven sites for each of these nutrients) and extractable $\mathrm{K}(P<0.05$ at six of the seven sites). Overall, there was little difference in the response between grass and arable sites, and sites with a prior history of organic material additions (Table 6), which suggested that the addition of organic materials had improved soil nutrient status over a relatively short time-frame (within 3 years). The greatest increases in topsoil nutrient status were following FYM applications, which increased topsoil total $\mathrm{N}$ by on average $10 \%$, extractable $\mathrm{P}$ by c. $35 \%$, extractable $\mathrm{K}$ by c. $80 \%$ and extractable $\mathrm{Mg}$ by c. $20 \%$. Moreover, the capacity of soils to retain and exchange nutrient cations was also improved, as measured by the cation exchange capacity (CEC), with significant treatment effects measured at

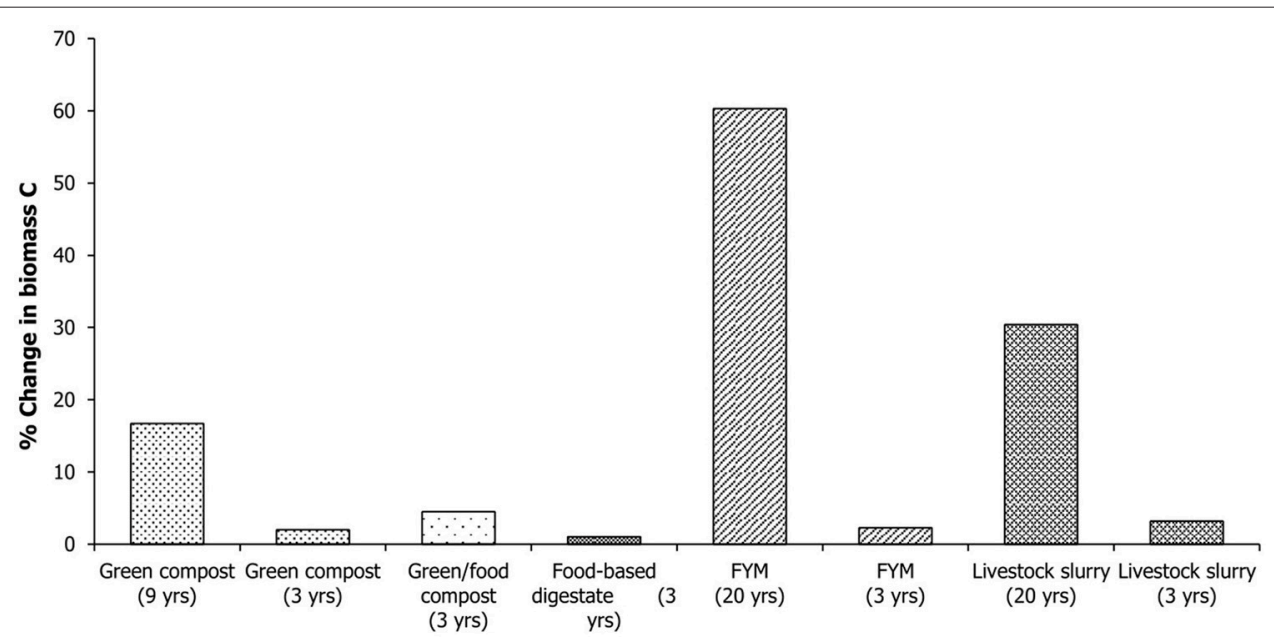

FIGURE 2 | Change in soil microbial biomass carbon following the repeated addition of organic materials for 3 and 9-20 years. Results are expressed as a percentage difference from the control treatment averaged over two sites with a prior history of green compost, FYM, and slurry additions, five sites with 3 years of green compost, FYM, and slurry additions and seven sites with 3 years of food-based digestate and green/food compost additions.

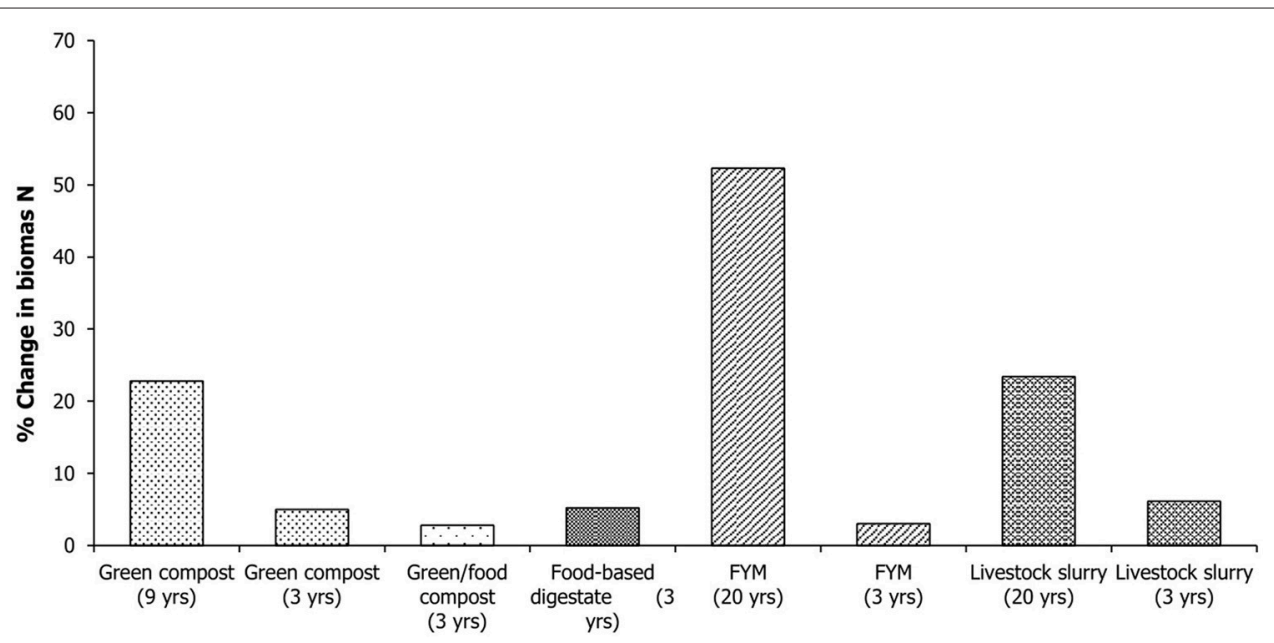

FIGURE 3 | Change in soil microbial biomass nitrogen following the repeated addition of organic materials for 3 and 9-20 years. Results are expressed as a percentage difference from the control treatment averaged over two sites with a prior history of green compost, FYM, and slurry additions, five sites with 3 years of green compost, FYM, and slurry additions and seven sites with 3 years of food-based digestate and green/food compost additions. 
TABLE 7 | Percentage change in topsoil nutrient status and cation exchange capacity (CEC) following the repeated addition of organic materials.

\begin{tabular}{lccccc}
\hline Treatment & Total N & Ext. P & Ext. K & Ext Mg & CEC \\
\hline Green compost & 9.1 & 6.6 & 33.3 & 8.3 & 6.7 \\
Green/food compost & 6.2 & 9.8 & 21.3 & -3.1 & 3.3 \\
Food-based digestate & 2.6 & 2.4 & 20.9 & -9.2 & 1.1 \\
FYM & 8.1 & 36.8 & 84.3 & 17.8 & 7.0 \\
Livestock slurry & 4.2 & 9.1 & 48.2 & 10.1 & 0.4 \\
\hline
\end{tabular}

Results are expressed as a percentage difference from the control treatment averaged across all seven sites.

two of the seven sites (Harper Adams and Lampeter), and weak evidence of an effect across all sites (Table 6). Here, the application of bulky organic materials (green compost and FYM) resulted in the greatest increases $(6-7 \%$ increase relative to the control).

The organic material additions had a significant effect on topsoil $\mathrm{pH}$ at four of the seven experimental sites, namely, the two grassland sites and those with a prior history of organic material additions. This was confirmed by the modeling results which showed strong evidence of a difference between grass and arable sites and weak evidence of a prior history effect (Table 6). At the grassland sites, $\mathrm{pH}$ tended to increase by $0.3-$ $0.5 \mathrm{pH}$ units where all organic materials had been applied, most likely a reflection of the $\mathrm{pH}$ (and neutralizing value) of the organic materials. The only exception was on the foodbased digestate treatment at Lampeter where $\mathrm{pH}$ decreased by 0.2 units, which was probably a reflection of the local soil conditions (e.g., buffering capacity and moisture content) in combination with the acidifying effect of the nitrification process as the ammonium- $\mathrm{N}$ within the digestate was converted to nitrate-N. At the two arable sites with a prior history, the $\mathrm{pH}$ was increased by $0.3-0.5$ units on the long-term FYM and livestock slurry treatments (but not the green compost; $P<0.05$ ), again most likely reflecting the $\mathrm{pH}$ of the applied materials, but only apparent where these materials had been applied for 20 years.

Topsoil potentially mineralisable $\mathrm{N}(\mathrm{PMN})$, a biological measure of the soils capacity to supply $\mathrm{N}$ through the mineralization of soil organic $\mathrm{N}$ reserves, also increased following FYM and livestock slurry additions at three of the seven experimental sites (Devizes, Harper Adams, and Terrington, $P<0.05$ ), with the multipredictor modeling results showing a strong treatment affect which was similar across all sites. There was no improvement in model fit by comparing grass and arable sites or sites with a prior history (Table 6). However, two of the three sites with significant treatment effects were those with a prior history of organic material applications, with the relative increase in PMN (compared to the fertilizer only control) most marked where FYM, livestock slurry and green compost had been applied for 9+ years (Figure 4). Again, differences were proportionally greater where FYM had been applied for $c .20$ years ( $>100 \%$ increase) compared to green compost additions over 9 years (c.60\% increase), despite similar total SOC and total $\mathrm{N}$ contents.

\section{Soil Physical Properties}

There was a marked improvement in the multipredictor model fits for the variation in topsoil bulk density across the sites due to treatment (i.e., AIC improved by $>6$ ), with grassland sites responding differently to arable sites, and a weak improvement in the model fit due to prior history (AIC improved by 2-6; Table 6). At the arable sites, the application of bulky organic materials (i.e., FYM and green compost) for 9 or more years resulted in lower BD and consequently higher porosity; these treatments also had the highest SOC contents (Figure 1). Unlike the changes in $\mathrm{SOC}$, the decrease in $\mathrm{BD}$ was greater following repeated addition of FYM (c.8\% decrease relative to the control) compared to green compost (c.5\% decrease relative to the control), despite the similar total SOC contents (Figure 5). This was similar to the pattern observed for both microbial biomass and PMN (Figures 2-4).

The topsoil bulk density at the grassland sites responded differently to the applied treatments compared with the arable sites (Table 6). Grassland soils generally have inherently lower bulk density than arable soils (largely due to higher SOC contents). At both of the grassland sites there were small (c.5\%) decreases in bulk density following the application of compost and FYM for 3 years, which were statistically significant at Ayr $(P<0.05)$ and marginal $(P=0.06)$ at Lampeter. However bulk density increased (and porosity decreased), where organic materials with a low dry matter content (i.e., food-based digestate and livestock slurry) had been applied (Figure 6).

Results from the modeling exercise also revealed a weak effect of treatment on topsoil shear strength (a measure of the force required to work the soil), but no differences between grass and arable sites and no effect of prior history (Table 6). Looking in more detail at the individual site analyses, shear strength decreased at Harper Adams following the application of green compost, FYM and livestock slurry for 9 or more years $(P<0.05)$, with no treatment effects observed at the sites where materials had only been applied for 3 years. Again the decrease in shear strength at Harper Adams was greater on the longterm FYM treatment (c.20\% decrease relative to the control) compared to the long-term green compost and livestock slurry treatments (c.10\% decrease). By contrast, topsoil shear strength (and penetration resistance) at the Ayr grassland site increased following 3 years of food-based digestate $(P<0.05)$, with no effect of the other organic material treatments.

The decreases in soil bulk density (and increases in porosity) did not, however, lead to statistically significant increases in the total available water capacity (AWC) at any of the sites. However, the multipredictor modeling suggested a significant effect of treatment on the volumetric water content held at field capacity ( 0.05 bar), 2 bar and 15 bar and the easily available water capacity (EAWC-water held between field capacity and 2 bar pressure), with the model fits markedly improved by taking into account land use (i.e., grass/arable; Table 6). Inspection of the individual site analyses revealed an increase in the volumetric water content held at field capacity, 2 and 15 bar where FYM and to a lesser extent, green compost had been applied at the Lampeter grassland site $(P<0.05)$, but a decrease in EAWC where food-based digestate had been applied at Ayr $(P<0.05)$. 


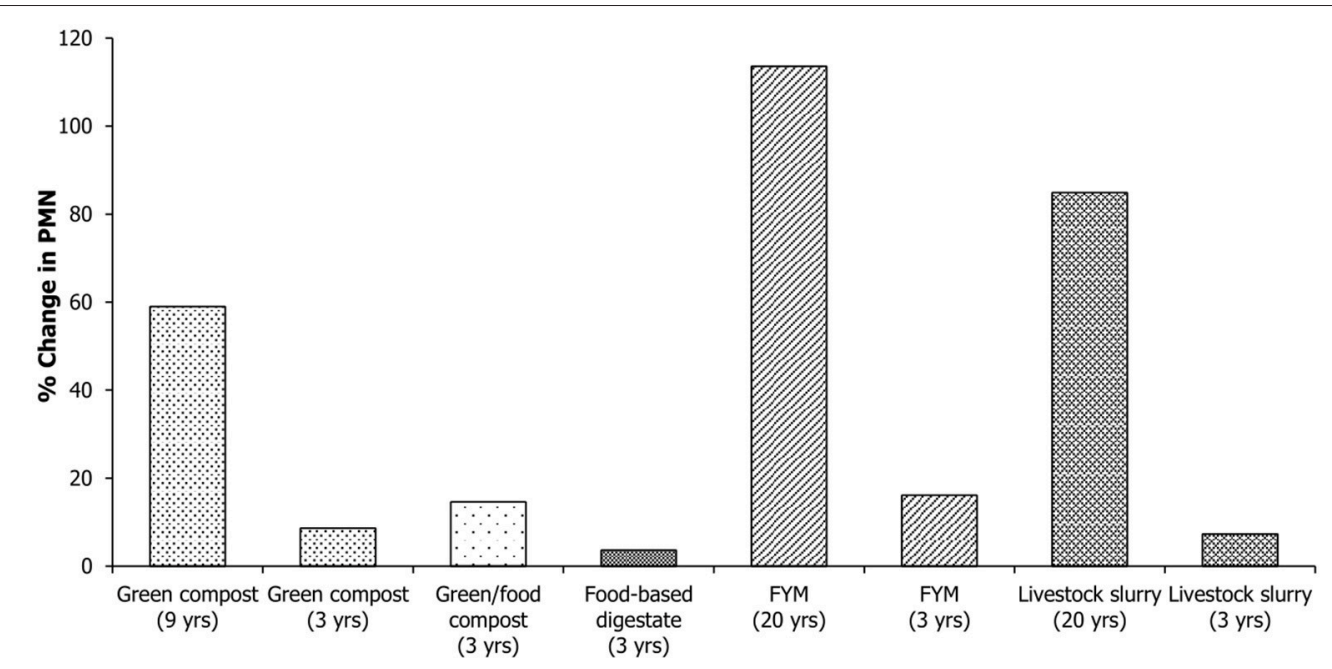

FIGURE 4 | Change in potentially mineralisable nitrogen (PMN) following the repeated addition of organic materials for 3 and 9-20 years. Results are expressed as a percentage difference from the control treatment averaged over two sites with a prior history of green compost, FYM, and slurry additions, five sites with 3 years of green compost, FYM, and slurry additions and seven sites with 3 years of food-based digestate and green/food compost additions.

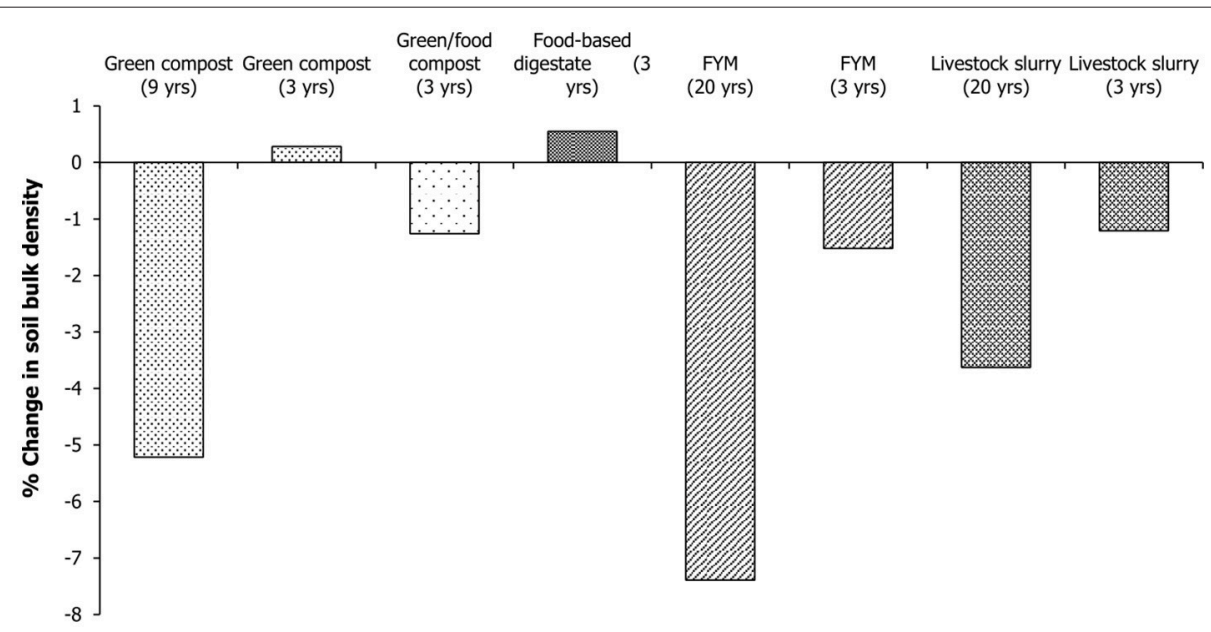

FIGURE 5 | Change in soil bulk density following the repeated addition of organic materials for 3 and over 9 years at the arable sites. Results are expressed as a percentage difference from the control treatment.

These differences were most likely due to changes in $\mathrm{BD}$ (which was used to calculate the volumetric moisture content). There were no treatment effects on the volumetric moisture contents at the arable sites ( $P$ values ranged from 0.13 to 0.95 , except at Aberdeen where $P=0.06$ for the 2 bar measurement).

\section{DISCUSSION}

The results from this multi-site field study have provided further evidence of the beneficial effects to soil quality and health of recycling different organic materials to agricultural land. Some soil properties such as nutrient status $(\mathrm{N}, \mathrm{P}, \mathrm{K}, \mathrm{Mg})$, responded to all organic material additions (both solid and liquid) within a short timescale ( $<3$ years), but other properties, such as total SOC, microbial biomass, and selected soil physical properties only changed to a statistically significant extent after multiple applications ( 9 or more years) of bulky organic materials (compost and FYM).

Given the central role of SOC in driving soil processes and properties (Kibblewhite et al., 2008), sustainable soil management is very much about managing SOC (Newell Price et al., 2015). Comparable increases in SOC were observed for both 9 years of green compost additions and 20 years of FYM additions. The capacity of a soil to hold OC is finite, such that after a change in management practice SOC may increase (e.g., after the introduction of regular organic material additions) or decrease (e.g., after plowing out long-term grass) toward an equilibrium (after 100 years or more) that is characteristic of the 


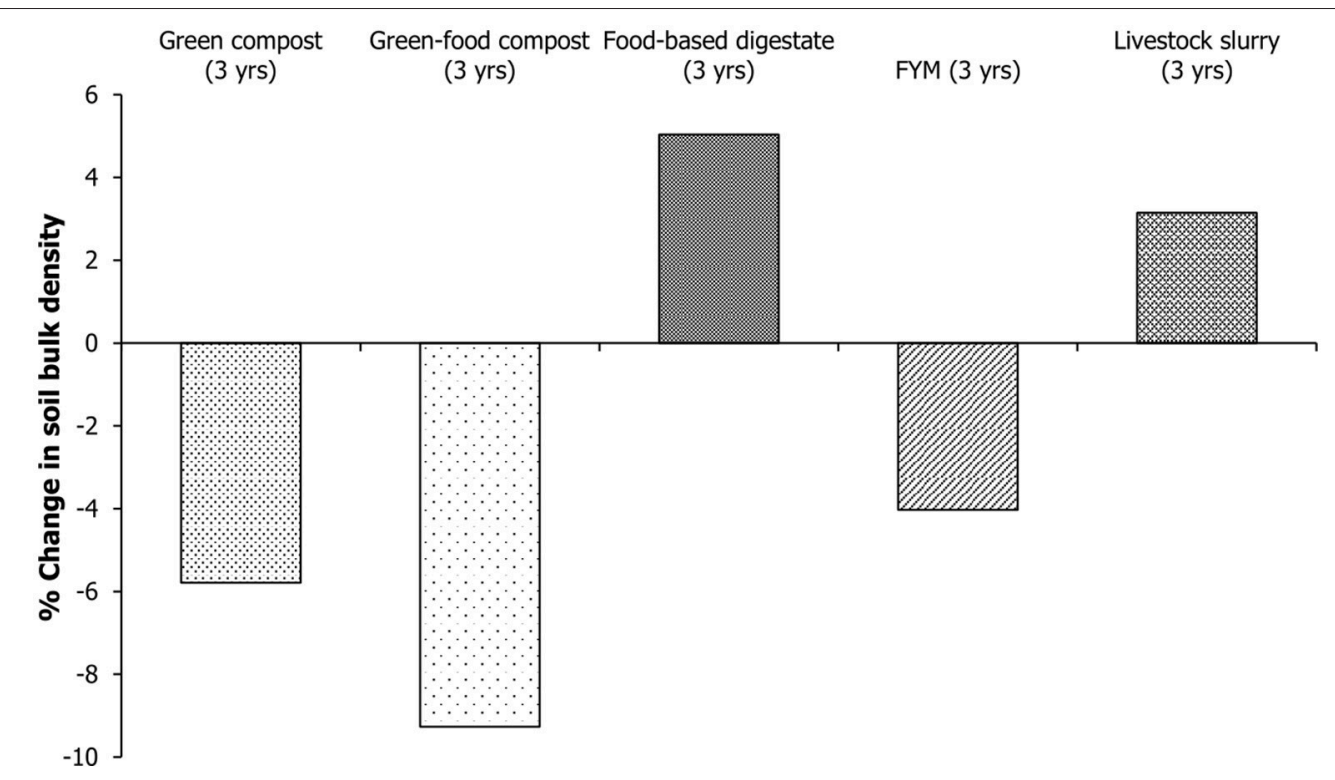

FIGURE 6 | Change in soil bulk density following the repeated addition of organic materials for 3 and over 9 years at the grassland sites. Results are expressed as a percentage difference from the control treatment.

soil type, land use and climate (Powlson et al., 2012). Annual rates of SOC accumulation (or depletion) therefore change over time and gradually decline to zero as the new equilibrium is approached. Typically, c.50\% of the SOC accumulation achieved after 100 years of introducing a management change, occurs within the first 20 years (Powlson et al., 2012). It is possible that the rate of SOC accumulation on the long-term FYM treatment at Harper Adams and Terrington was entering this slower phase. However, the retention of OC supplied by the green compost was almost double that of the FYM, suggesting that the OC in green compost was in a more stable form, due to loss of labile C during the composting process. The higher lignin content of the green compost (c.70\%) compared to the FYM (c.55\%) supports this conclusion. The greater stability of the OC supplied by the green compost additions therefore enabled a more rapid buildup of SOC over a shorter timeframe. Retention of OC from the FYM was $c .12 \%$, which is identical to that reported by Maillard and Angers (2014) in a global meta-analysis of long-term field experiments with animal manures. Retention of compost OC (at 20-25\%) was almost double that of FYM, although not as great as that reported by Bhogal et al. (2010) from four UK studies where green compost had been applied for 5-8 years and OC retention was over $40 \%( \pm 8 \%)$. Given the interest in exploring potential land management strategies for increasing soil carbon storage in the mitigation of climate change, these OC retention coefficients are useful for improving national GHG inventory methodologies (Maillard and Angers, 2014) and demonstrate the value of green compost for increasing soil carbon storage.

A key result, however, was that whilst green compost was found to be a good source of stable organic $\mathrm{C}$ able to build-up SOC pools over a relatively short time-frame, it did not produce the same level of improvement in associated soil biological and physical functioning as a similar increase in SOC produced by FYM applications (albeit over a longer time period and with a higher OC loading-another 4-6 years of experimentation would be required in order to establish whether a similar green compost OC loading could achieve the same level of improvement in soil biological and physical functioning as achieved on the long-term FYM treatment). As a more readily decomposable C source, the SOC increase induced by the FYM applications was able to support a bigger microbial population than that produced by the green compost additions. Importantly, this also led to a proportionally greater improvement in soil physical functioning (BD, porosity, and workability) and provides field evidence of the influence of the microbial community in the development of soil structure which has hitherto predominantly been concluded from laboratory studies (e.g., Watts et al., 2001, 2005). Moreover, it demonstrates the importance of the quality (particularly the C composition) of organic inputs, as well as the quantity, in influencing soil quality. Indeed, in a laboratory study Watts et al. (2005) clearly demonstrated the involvement of the soil microbial community in soil aggregation, with the incorporation of grass residues (with a low C:N ratio) resulting in greater micro-aggregation than straw incorporation, and no aggregation occurring where charcoal (with a C:N ratio of 600) was incorporated.

The extent of decomposition of organic matter that is added to soil is one of the important factors that define the "quality" of the amendment. Composting increases the proportion of aromatic structures (Chefetz et al., 1996), which will influence the composition of the resultant soil organic matter (Spaccini et al., 2009) and the soil biological community it supports (e.g., Ros et al., 2006). For example, Lucas et al. (2014), in a laboratory 
incubation study, observed that the formation of large macroaggregates was highest in soils amended with vetch, followed by livestock manure, with green compost either having no effect or reducing aggregate formation relative to a non-amended control. This was related to the amount of microbially available C supplied by the different materials and the composition of soil microbial community they supported, with the vetch and manure providing greater amounts of labile $\mathrm{C}$ and a shift toward fungal-dominated soil microbial communities. In a 9 year field experiment, Annabi et al. (2011) observed that the addition of three different composts (municipal solid waste, sewage sludge/green waste, and a biowaste compost) had a larger positive effect on aggregate stability than FYM. Compost derived from municipal solid waste was the most efficient in improving aggregate stability in the first 6 years of the experiment due to a larger labile organic C content stimulating soil microbial activity. However, after the first 6 years, the two other, more stable composts, became more efficient, linked to a greater increase in soil organic $\mathrm{C}$ contents.

The "quality" of the organic materials applied not only affects the soil microbial community response, but has also has implications for the whole of the soil food web. For example, Leroy et al. (2008) measured significant differences in earthworm populations following repeated organic material additions (four applications over $c .2$ years), with FYM and cattle slurry having the highest earthworm abundance, compost intermediate, and an un-amended control having the lowest earthworm numbers. Stroud et al. (2016) measured a similar effect when comparing 3 years of FYM and compost additions, with the compost having no impact on the abundance of Lumbricus terrestris earthworms, whereas FYM increased abundance by c.38\%. Rates of OC addition were the same for all treatments in these experiments, with the different earthworm abundance attributed to differences in the nutritional value of the organic materials.

Application of organic materials with a low dry matter content (digestate and livestock slurries) produced few measurable changes in soil properties in the short-term. Indeed, these materials are typically applied to recycle nutrients to the soil/crop system and reduce the need for manufactured fertilizer, rather than to improve SOC levels and overall soil quality. In fact, Coban et al. (2015) observed that the application of digestate (derived from livestock manures) caused a priming effect resulting in the mineralization of native soil organic matter and concluded that intensive and repeated application of such materials "should be avoided" due to the potential to decrease SOC. However, SOC levels were not $(P>0.05)$ affected by the short-term $(<3$ years $)$ application of digestate and livestock slurry in this study. Moreover, in the long-term (i.e., up to 20 years) repeated livestock slurry additions increased SOC and soil biological and physical functioning, although not to the same level as comparable applications of FYM. It is therefore possible that repeated digestate applications over a similar timeframe could lead to similar improvements. Nkoa (2014) reviewed evidence from a number of studies which suggested that in the majority of cases, the short-term effects of digestate application resulted in an improvement in soil quality (microbial biomass, $\mathrm{N}$ and $\mathrm{P}$ contents), with one study reporting a reduction in bulk density and increase in soil moisture retention (Garg et al., 2005).

At the grassland sites, compost and FYM additions decreased bulk density, but there was evidence of soil compaction (i.e., increased bulk density) where digestate and livestock slurry had been applied for 3 years. Soil compaction is often observed where livestock slurries have been applied due to heavy trafficking by the tanker during application, particularly if conducted under wet conditions. However on almost all occasions, all the organic materials (including the livestock slurries and digestates) were applied by hand, so it is unlikely that soil compaction occurred as a result. It is possible that the volume, viscosity and conductivity of the liquids applied may have caused partial break-down (slaking) of the surface soil aggregates, leading to a decrease in porosity and increase in bulk density. However, this has not been widely reported as a problem with slurry applications to grassland and further experimentation would be required in order to elucidate the reasons behind the observed increases in bulk density.

\section{CONCLUSIONS}

The results provide robust evidence of the soil quality benefits of recycling organic materials to agricultural land. However, the level and nature of benefit depends on both the quantity (carbon loading) and quality (decomposability) of the organic material applied. Most organic materials are valuable sources of plant nutrients, enabling a reduction in manufactured fertilizer use. However, significant improvements in soil biological and physical functioning appear to be dependent on supplying sufficient OC that is biologically available (e.g., materials with a low C:N and concentration of aromatic compounds). In this study, this was achieved through repeat addition of FYM. Where more rapid increases in SOC are required, to increase soil carbon storage for example, then materials which are more resistant to decomposition, such as composts, would be more beneficial.

\section{AUTHOR CONTRIBUTIONS}

$A B$ led the research project from which this paper was written, supported by FN. AR undertook much of the data analysis together with MW who performed the multi-predictor modeling. AL managed the Scottish experimental sites. JW and MT oversaw the whole DC-Agri experimental programme which this work contributed to.

\section{ACKNOWLEDGMENTS}

This work was commissioned by WRAP and Zero Waste Scotland and funded by Defra, Scottish, and Welsh Government $^{2}$. The authors wish to acknowledge the large number of people at ADAS, Harper Adams University and SRUC who have made an invaluable contribution to this project.

\footnotetext{
${ }^{2}$ www.wrap.org.uk/dc-agri.
} 


\section{REFERENCES}

Anderson, T. H., and Domsch, K. H. (1989). Ratios of microbial biomass carbon to total organic carbon in arable soils. Soil Biol. Biochem. 21, 471-479. doi: 10.1016/0038-0717(89)90117-X

Annabi, M., Le Bissonnais, Y., Le Villio-Poitrenaud, M., and Houot, S. (2011). Improvement of soil aggregate stability by repeated applications of organic amendments to a cultivated silty loam soil. Agric. Ecosyst. Environ. 144, 382-389. doi: 10.1016/j.agee.2011.07.005

Bhogal, A., Chambers, B. J., Whitmore, A. P., and Powlson, D. S. (2010). Effects of Reduced Tillage Practices and Organic Material Additions on the Carbon Content of Arable Soils. Final report to Defra for project SP0561. Available online at: randd.defra.gov.uk/Document.aspx?Document=SP0561_6892_FRP.doc

Bhogal, A., Nicholson, F. A., and Chambers, B. J. (2009). Organic carbon additions: effects on soil bio-physical and physico-chemical properties. Eur. J. Soil Sci. 60, 276-286. doi: 10.1111/j.1365-2389.2008.01105.x

Bhogal, A., Nicholson, F. A., Young, I., Sturrock, C., Whitmore, A. P., and Chambers, B. J. (2011). Effects of recent and accumulated livestock manure carbon additions on soil fertility and quality. Eur. J. Soil Sci. 62, 174-181. doi: 10.1111/j.1365-2389.2010.01319.x

Bhogal, A., Nicholson, F., Taylor, M., Rollett, A., and Williams, J. (2016). Crop available nitrogen supply from food-based digestate. Int. Fertil. Soc. Proc. 790, 1-15. Available online at: http://fertiliser-society.org/proceedings/ uk/Prc790.HTM

Brookes, P. C., Landman, A., Pruden, G., and Jenkinson, D. S. (1985). Chloroform fumigation and the release of soil nitrogen: a rapid direct extraction method to measure microbial biomass nitrogen in soil. Soil Biol. Biochem. 17, 837-842. doi: 10.1016/0038-0717(85)90144-0

BSI (2011). PAS 100:2011 Specification for Composted Materials. Available online at: http://www.wrap.org.uk/content/bsi-pas-100-compost-specification-1

BSI (2014). PAS 110:2014 Specification for Whole Digestate, Separated Liquor and Separated Fibre Derived from the Anaerobic Digestion of source Segregated Biodegradable Materials. Available online at: www.wrap.org.uk/content/bsipas-110-producing-quality-anaerobic-digestate

Chefetz, B., Hatcher, P. G., Hadar, Y., and Chen, Y. (1996). Chemical and biological characterization of organic matter during composting of municipal solid waste. J. Environ. Qual. 25, 776-785.

Coban, H., Miltner, A., Elling, F. J., Hinrichs, K. U., and Kastner, M. (2015). The contribution of biogas residues to soil organic matter formation and $\mathrm{CO}_{2}$ emissions in an arable soil. Soil Biol. Biochem. 86, 108-115. doi: 10.1016/j.soilbio.2015.03.023

Defra (2010). The Fertiliser Manual (RB209). Norwich: The Stationary Office.

DECC and Defra (2011). Anaerobic Digestion Strategy and Action Plan. Defra, London. Available online at: http://www.defra.gov.uk/publications/files/ anaerobic-digestion-strat-action-plan.pdf

Diacono, M., and Montemurro, F. (2010). Long-term effects of organic amendments on soil fertility. a review. Agron. Sustain. Dev. 30, 401-422. doi: 10.1051/agro/2009040

Edmeades, D. C. (2003). The long-term effects of manures and fertilisers on soil productivity and quality: a review. Nutr. Cycl. Agroecosyst. 66, 165-180. doi: 10.1023/A:1023999816690

European Union (2015). Closing the Loop - An EU Action Plan for the Circular Economy. Available online at: http://eur-lex.europa.eu/legal-content/ EN/TXT/?uri=CELEX:52015DC0614

Garg, R. N., Pathak, H., Das, D. K., and Tomar, R. K. (2005). Use of flyash and biogas slurry for improving wheat yield and physical properties of soil. Environ. Monit. Assess. 107, 1-9. doi: 10.1007/s10661-005-2021-x

Johnston, A. E., Poulton, P. R., and Coleman, K. (2009). Soil organic matter: its importance in sustainable agriculture and carbon dioxide fluxes. Adv. Agron. 101, 1-57. doi: 10.1016/S0065-2113(08)00801-8

Keeney, D. R. (1982). "Nitrogen availability indices," in Methods of Soil Analysis, Part 2, Chemical and Microbiological Properties, eds A. L. Page, R. H. Miller, and D. R. Keeney (Madison, WI: American Society of Agronomy), 199-244.

Kibblewhite, M. G., Ritz, K., and Swift, M. J. (2008). Soil health in agricultural systems Phil. Trans. R. Soc. B 363, 685-701. doi: 10.1098/rstb. 2007.2178

Leroy, B. L. M., Schmidt, O., Van den Bosschea, A., Reheul, D., and Moensd, M. (2008). Earthworm population dynamics as influenced by the quality of exogenous organic matter Pedobiologia 52, 139-150. doi: 10.1111/ejss. 12025

Litterick, A. (2009). The effect of composts and digestate on a spring barley crop. Final report to WRAP for project OAV023-017. Available online at: www.wrap. org.uk

Lucas, S. T., D’Angelo, E. M., and Williams, M. A. (2014). Improving soil structure by promoting fungal abundance with organic soil amendments. Appl. Soil Ecol. 75, 13- 23. doi: 10.1016/j.apsoil.2013.10.002

MAFF (1982). Techniques for Measuring Soil Physical Properties. MAFF Reference Book 441. London: HMSO.

MAFF (1986). The Analysis of Agricultural Materials. MAFF Reference Book 427. London: HMSO.

Maillard, É., and Angers, D. A. (2014). Animal manure application and soil organic carbon stocks: a meta-analysis. Glob. Chang. Biol. 20, 666-679. doi: $10.1111 /$ gcb.12438

Newell Price, P., Smith, K., Bhogal, A., Sagoo, L., and Collins, C. (2015). Soil Research Evidence Review. Report to Defra SP1620. Available online at: http:// randd.defra.gov.uk.

Nicholson, F. A., Anthony, S., and Chambers, B. J. (2008). The National Inventory and Map of Livestock Manure Loadings to Agricultural Land: MANURE-GIS. Final report, Defra project WQ0103.

Nicholson, F., Bhogal, A., Cardenas, L., Misselbrook, T., Rollett, A., Taylor, T., et al. (2017). Nitrogen losses to the environment following food-based digestate and compost applications to agricultural land. Environ. Poll. 228, 504-516. doi: 10.1016/j.envpol.2017.05.023

Nicholson, F. A., Bhogal, A., Chadwick, D., Gill, E., Gooday, R. D., Lord, E., et al. (2013). An enhanced software tool to support better use of manure nutrients: MANNER-NPK. Soil Use Man. 29, 473-484. doi: 10.1111/sum.12078

Nkoa, R. (2014). Agricultural benefits and environmental risks of soil fertilisation with anaerobic digestates: a review. Agron. Sustain. Dev. 34, 473-492. doi: 10.1007/s13593-013-0196-z

Peltre, C., Nyord, T., Bruun, S., Jensen, L. S., and Magid, J. (2015). Repeated soil application of organic waste amendments reduces draught force and fuel consumption for soil tillage. Agric. Ecosyst. Environ. 211, 94-101. doi: 10.1016/j.agee.2015.06.004

Powlson, D. S., Bhogal, A., Chambers, B. J., Coleman, K., Macdonald, A. J., Goulding, K. W. T., et al. (2012). The potential to increase soil carbon stocks through reduced tillage or organic material additions in England and Wales: a case study. Agri. Ecosyst. Environ. 146, 23-33. doi: 10.1016/j.agee.2011. 10.004

Rasmussen, P. E., Allmaras, R. R., Rohde, C. R., and Roager, N. C. Jr. (1980) Crop residue influences on soil carbon and nitrogen in a wheat-fallow system. Soil Sci. Soc. Am. J. 44, 596-600. doi: 10.2136/sssaj1980.036159950044000 $30033 x$

R Core Team (2014). R: A Language and Environment for Statistical Computing. Vienna: R Foundation for Statistical Computing. Available online at: http:// www.R-project.org/

Richards, S. A. (2005). Testing ecological theory using the informationtheoretic approach: examples and cautionary results. Ecology 86, 2805-2814. doi: 10.1890/05-0074

Richards, S. A. (2008). Dealing with overdispersed count data in applied ecology. J. Appl. Ecol. 45, 218-227. doi: 10.1111/j.1365-2664.2007.01377.x

Ros, M., Klammer, S., Knapp, B., Aichberger, K., and Insam, H. (2006). Long-term effects of compost amendment of soil on functional and structural diversity and microbial activity. Soil Use Manage. 22, 209-218. doi: 10.1111/j.1475-2743.2006.00027.x

SAC (2010). Phosphorus, Potassium, Sulphur and Magnesium Recommendations for Cereals, Oilseed Rape and Potatoes. Technical Note TN633, SAC August 2010.

Schröder, J. J., Jansen, A. G., and Hilhorst, G. J. (2005). Long-term nitrogen supply from cattle slurry. Soil Use Manage. 21, 196-204. doi: 10.1079/SUM20 05306

Spaccini, R., Sannino, D., Piccolo, A., and Fagnano, M. (2009). Molecular changes in organic matter of a compost-amended soil. Eur. J. Soil Sci. 60, 287-296. doi: 10.1111/j.1365-2389.2008.01108.x

Stroud, J. L., Irons, D., Watts, C. W., and Whitmore, A. P. (2016). Lumbricus terrestris abundance is not enhanced after three years of compost amendments on a reduced tillage wheat cultivation conversion. Agric. Ecosyst. Environ. Appl. Soil Ecol. 98, 282-284. doi: 10.1016/j.apsoil.2015.10.007 
Verzani, J. (2014). Using $R$ for Introductory Statistics. Boca Raton, FL: CRC/Chapman and Hall Press.

Water, U. K. (2010). Recycling of Biosolids to Agricultural Land. Queen Anne's Gate, London.

Watts, C. W., Whalley, W. R., Brookes, P. C., Devonshire, J., and Whitmore, A. P. (2005). Biological and physical processes that mediate micro-aggregation of clays. Soil Sci. 170, 573-583. doi: 10.1097/01.ss.0000178206.74040.0c

Watts, C. W., Whalley, W. R., Longstaff, D. J., White, R. P., Brooke, P. C., and Whitmore, A. P. (2001). Aggregation of a soil with different cropping histories following the addition of organic materials. Soil Use Manage. 17, 263-268. doi: 10.1079/SUM200189

WRAP (2013). A Survey of the UK Organics Recycling Industry in 2012 - A Report on the Structure of the UK Organics Treatment/Recycling Sector and the Markets for its Outputs.Available online at: www.wrap.org.uk

WRAP (2014). A Survey of the UK Anaerobic Digestion Industry in 2013. Available online at: www.wrap.org.uk
Wu, J., Joergensen, R. G., Pommerening, B., Chaussod, R., and Brookes, P. C. (1990). Measurement of soil microbial biomass C by fumigationextraction - an automated procedure. Soil Biol. Biochem. 22, 1167-1169. doi: 10.1016/0038-0717(90)90046-3

Conflict of Interest Statement: The authors declare that the research was conducted in the absence of any commercial or financial relationships that could be construed as a potential conflict of interest.

Copyright (c) 2018 Bhogal, Nicholson, Rollett, Taylor, Litterick, Whittingham and Williams. This is an open-access article distributed under the terms of the Creative Commons Attribution License (CC BY). The use, distribution or reproduction in other forums is permitted, provided the original author(s) and the copyright owner are credited and that the original publication in this journal is cited, in accordance with accepted academic practice. No use, distribution or reproduction is permitted which does not comply with these terms. 